\title{
Impact of surgical experience on early post-operative regional corneal thickness after phacoemulsification
}

\begin{tabular}{|c|c|}
\hline \multicolumn{2}{|c|}{$\begin{array}{l}\text { Authors: } \\
\text { Yousif F. Dawood } \\
\text { Ammar F. Issa } \\
\text { Essam S. Faraj }\end{array}$} \\
\hline \multicolumn{2}{|c|}{$\begin{array}{l}\text { Affiliations: } \\
{ }^{1} \text { Department of } \\
\text { Ophthalmology, College of } \\
\text { Medicine, University of } \\
\text { Anbar, Anbar, Iraq }\end{array}$} \\
\hline \multicolumn{2}{|c|}{$\begin{array}{l}\text { Department of } \\
\text { Ophthalmology, Ibn Al } \\
\text { Haitham Teaching Eye } \\
\text { Hospital, Baghdad, Iraq }\end{array}$} \\
\hline \multicolumn{2}{|c|}{$\begin{array}{l}\text { 3Jenna Ophthalmic Center, } \\
\text { Baghdad, Iraq }\end{array}$} \\
\hline \multicolumn{2}{|c|}{$\begin{array}{l}\text { Corresponding author: } \\
\text { Yousif Dawood, } \\
\text { med.yoseif.alrawi@uoanbar. } \\
\text { edu.iq }\end{array}$} \\
\hline \multicolumn{2}{|c|}{$\begin{array}{l}\text { Dates: } \\
\text { Received: } 15 \text { Apr. } 2020 \\
\text { Accepted: } 11 \text { Sept. } 2020 \\
\text { Published: } 15 \text { Feb. } 2021\end{array}$} \\
\hline \multicolumn{2}{|c|}{$\begin{array}{l}\text { How to cite this article: } \\
\text { Dawood YF, Issa AF, Faraj ES. } \\
\text { Impact of surgical experience } \\
\text { on early post-operative } \\
\text { regional corneal thickness } \\
\text { after phacoemulsification. } \\
\text { Afr Vision Eye Health. } \\
2021 ; 80(1) \text {, a572. https://doi. } \\
\text { org/10.4102/aveh.v80i1.572 }\end{array}$} \\
\hline \multicolumn{2}{|c|}{$\begin{array}{l}\text { Copyright: } \\
\text { (c) 2021. The Author(s). } \\
\text { Licensee: AOSIS. This work } \\
\text { is licensed under the } \\
\text { Creative Commons } \\
\text { Attribution License. }\end{array}$} \\
\hline \multicolumn{2}{|l|}{ Read online: } \\
\hline 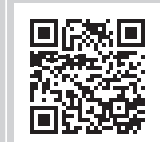 & $\begin{array}{l}\text { Scan this QR } \\
\text { code with your } \\
\text { smart phone or } \\
\text { mobile device } \\
\text { to read online. }\end{array}$ \\
\hline
\end{tabular}

Background: Currently, phacoemulsification is a very common cataract surgical procedure in which the lens is emulsified and aspirated from the eye through a small corneal incision.

Aim: To compare early regional corneal thickness changes following phacoemulsification done by experienced surgeons versus trainee surgeons.

Setting: A prospective cohort study was done at Ibn Al Haitham tertiary eye hospital in Baghdad, Iraq.

Methods: The data were collected for 5 months, from 01 March 2018 until 31 July 2018. Adult patients undergoing phacoemulsification and intraocular lens surgery were prospectively evaluated and divided into two groups. Group 1 comprised those operated by experienced surgeons, whilst Group 2 patients were operated by trainee surgeons. Slit lamp examination and endothelial specular microscopy were assessed with the measurement of central corneal thickness (CCT) and peripheral corneal thickness (PCT), using Scheimpflug imaging (Pentacam).

Results: There was a significant statistical difference in post-operative CCT between Groups 1 and 2, being $596.72 \pm 50.69 \mu \mathrm{m}$ compared to $631.54 \pm 67.84 \mu \mathrm{m}$ in Groups 1 and 2, respectively, with a mean difference of $34.82 \mu \mathrm{m}(p=0.000)$. More difference was observed in post-operative PCT $(148.38 \mu \mathrm{m})$ as it was $734.8 \pm 88.55 \mu \mathrm{m}$ in the experienced group, compared to $883.18 \pm$ $128.43 \mu \mathrm{m}$ in the trainee group $(p=0.005)$.

Conclusion: Phacoemulsification done by trainee surgeons was associated with higher CCT and PCT.

Keywords: phacoemulsification; cataract; central corneal thickness; peripheral corneal thickness; cumulative dissipated energy.

\section{Introduction}

The development of phacoemulsification surgery has resulted in a trend towards improved visual acuity with optimal safety and minimum invasiveness. ${ }^{1,2}$ Patient expectations have increased in conjunction with this trend. Therefore, faster recovery of visual acuity after the phacoemulsification has become important. ${ }^{3}$ This quick visual recovery may be attributed to several factors, including minimal inflammatory process, accurate intraocular lens calculations in addition to corneal clarity, which depends on minimal endothelial damage/ stress. ${ }^{4}$

Factors reported to cause damage to the endothelium include the amount of used ultrasound energy, collision of lens nucleus fragments with the corneal endothelium, ${ }^{5}$ air bubbles ${ }^{6}$ or a localised temperature rise, ${ }^{7}$ causing endothelial cell loss. In most cases, it is a short-lived phenomenon that presents as early and transient post-operative corneal oedema, which is a significant factor in hindering early visual recovery. ${ }^{8}$ If endothelial cell loss persists and cell count falls below a threshold of 500 cells per square millimeter, bullous keratopathy can occur. ${ }^{9}$

Regarding peripheral cornea, endothelial damage is a relatively common minor complication usually associated with the corneal incision (anterior or shelved incision), misdirected stream of fluid and viscoelastics that gains entry into the space between the stroma and Descemet's membrane by causing Descemet's membrane detachment. ${ }^{10,11}$

Corneal swelling increases light back-scattering, which results in reduction of contrast sensitivity and increased susceptibility to glare. ${ }^{12}$ This adverse event is of particular concern 
amongst post-operative patients because it directly influences final post-operative corneal transparency, which in turn can affect visual acuity. ${ }^{13}$

Surgeon experience may play a crucial role in preventing this early post-operative corneal oedema resulting from endothelial stress through efficient use of energy, minimal traumatic techniques for lens material removal, shorter operative time and shorter ultrasound time. ${ }^{9,14}$ During the learning curve, a trainee doctor is more likely to use longer phacoemulsification time and higher average ultrasound power and to require prolonged surgery time. ${ }^{15}$ There is an evidence that early introduction of cataract surgery training has the potential to improve the phacoemulsification learning curve and reduce complication rate of resident-performed surgeries. ${ }^{16}$

To measure the extent of post-operative corneal oedema, corneal pachymetry needs to be measured. A number of instruments have been developed to determine corneal thickness, including ultrasound pachymetry, optical pachymetry, contact and noncontact specular microscope, scanning slit topography/pachymetry, Scheimpflug tomography, corneal confocal microscopy, ultrasound biomicroscopy, partial coherence interferometry and optical coherence tomography. ${ }^{17}$

The Pentacam (Oculus GmbH, Germany) uses a rotating Scheimpflug camera providing a three-dimensional scan of the anterior eye segment; 25 images are captured within $2 \mathrm{~s}$. Various studies have verified its high reproducibility and repeatability in measuring central corneal thickness (CCT).$^{18,19}$ Pentacam provides repeatable and reproducible measurements in corneas with post-surgical corneal oedema. ${ }^{20}$

\section{Patients and methods}

A prospective cohort study was done at Ibn Al Haitham tertiary eye hospital in Baghdad/Iraq. Adult patients included were classified in two groups. Group 1 comprised those to be operated by experienced surgeons, whilst Group 2 were those to be operated by trainee surgeons under training programme of Arab Board in the third and fourth grades. All patients have undergone cataract phacoemulsification and intraocular lens (IOL) implantation. The data were collected for 5 months, from 01 March 2018 until 31 July 2018.

Experienced surgeons were defined as those who operated more than 1000 cases of phacoemulsification.

\section{Pre-operatively}

- Ethical committee approval was obtained for this study.

- After clinical history taking, all patients were assessed regarding visual acuity, refraction, intraocular pressure measurement by air puff tonometer.

- Patients were examined using slit-lamp for anterior and posterior segment examination and for cataract density assessment by applying a grading system that classify nuclear cataract into four grades (N1 to N4) according to the degree of nuclear cloudiness with the use of a slit beam of $0.1 \mathrm{~mm}$ shone at $45^{\circ}$ to compare the opacification of the central nuclear area to that of the anterior and posterior shell as follows:

- N1: Nucleus clearer than anterior/posterior sections

- N2: Nucleus equal to the anterior/posterior sections

- N3: Nucleus denser than anterior/posterior sections

- N4: Brunescent, Cataract completely opaque/brown

Three grades of cortical cataract were assessed by estimating the area of the peripheral spokes on retroillumination. Posterior subcapsular cataract was divided into three grades seen on retroillumination according to the vertical height of opacification measured in millimetres..$^{21}$

Patients were sent for specular microscopy (Topcon ${ }^{\circledR}$ SP3000P, Japan) to assess the endothelium status, and corneal topography by Pentacam (Oculus ${ }^{\circledast} \mathrm{GmbH}$, Germany), using the rotating Scheimpflug camera to obtain corneal thickness in micrometres both centrally and peripherally at the main incision site, which was set at the axis of $120^{\circ}$ in addition to observing the anterior chamber depth.

Both experienced and trainee surgeons were selected to be right handed. All patients included were operated using Alcon ${ }^{\circledR}$ Constellation vision system (Fort Worth, United States).

The phaco machine measures regarding irrigation, aspiration, vacuum and ultrasound were chosen by the operating surgeon. Patients received either retrobulbar or topical anaesthesia. Main incision was made using sharp keratome of $2.8 \mathrm{~mm}$ at the preset axis of $120^{\circ}$, diluted adrenaline was injected in the anterior chamber $(\mathrm{AC})$ to dilate the pupil, then trypan blue dye was used to stain the anterior capsule. Viscoelastic was used to inflate the AC after clearing the dye. Continuous curvilinear capsulorhexis was done using cystotome or rhexis forceps, followed by creating side port incision using $1.2 \mathrm{~mm}$ sharp blade at the axis of $70^{\circ}$. After hydrodissection \pm hydrodelineation, the cataract nucleus was emulsified using phaco handpiece with the preferred technique the surgeon is familiar with (stop and chop/direct chopping). Irrigation aspiration handpiece was then used to remove the cortical material. After filling the AC with viscoelastic, a single piece foldable acrylic IOL was injected in the capsular bag. Finally, excess viscoelastic was removed by irrigation aspiration handpiece, and wounds were sealed using stromal hydration.

\section{Post-operatively}

- Cumulative dissipated energy (CDE) was obtained from the display of the phacoemulsification device and it represents the overall ultrasound energy used during operation. It's calculated by multiplying the average energy by the total time of ultrasound, so higher levels 
indicates higher ultrasound energy is consumed during a longer period of time. ${ }^{22}$

- Corneal topography was repeated on day 1 postoperatively by the same device.

\section{Exclusion criteria}

- Diabetic patients.

- Glaucoma.

- History of trauma, uveitis, previous ocular surgery.

- Endothelial dystrophies.

- Pseudoexfoliation syndrome and pigment dispersion syndrome.

- Endothelial cell count below 1500 pre-operatively.

- Contact lens wearer.

- Complication during the cataract surgery.

- Anterior chamber depth less than $2.5 \mathrm{~mm}$ measured by Pentacam.

- Patients with poorly dilated pupil.

- Morgagnian and white cataract.

\section{Statistical analysis}

Data tabulation, input and coding was done by the use of IBM $^{\odot}$ SPSS $^{\odot}$ (Statistical Package for the Social Sciences) version 22.

To compare between two normally distributed variables, the independent sample $T$-test and paired sample $T$-test were used, whilst for any variable that did not follow a normal distribution the Mann-Whitney $U$ test, which is a nonparametric test was used. Analysis of variances (ANOVA) were used to compare between multiple numerical values, followed by Tukey's post hoc test to identify intergroup differences. To find the association of nuclear cataract grade and study groups, the Chi-square test was used. Pearson correlation modules and controlled partial correlation modules were done to assess the correlation between variables. Correlation coefficients from (r) of 0.7-0.8 were considered to have high correlation, 0.5-0.69 were considered to have moderate correlation, and values from 0.3 to 0.5 were considered to have weak correlation, and values between 0 and 0.3 were considered to have no relationship. $P$-value less than 0.05 was considered significant throughout data analysis. Linear regression modules were done to evaluate the linear relationship between CDE values and post-operative CCT and peripheral corneal thickness (PCT), according to the operating surgeons' experience.

\section{Ethical consideration}

The authors confirm that ethical approval was obtained for the study from the College of Medicine, University of Anbar, Iraq.

\section{Results}

A total of 100 patients were included in this study, their mean age was $57.21 \pm 9.74$ years, with almost equal numbers of males and females. The same applies to laterality, as shown in Table 1.
Comparing age and preoperative CCT and PCT showed statistically insignificant differences between patients operated by Group 1 or Group 2 surgeons, as shown in Table 2.

Comparing preoperative endothelium specular microscopic characteristics between the two groups showed statistically insignificant differences, as shown in Table 3.

There was an insignificant statistical association between study groups and grade of nuclear cataract, with close percentages of all grades between the two groups, as shown in Table 4 .

There was a significant statistical difference between Groups 1 and 2 in post-operative CCT, with a mean difference of $34.82 \mu \mathrm{m}$ between Groups 1 and $2(p=0.005)$. More difference was observed in PCT of $148.38 \mu \mathrm{m}$ $(p=0.000)$. The mean CDE used by trainee surgeons was twice the mean of CDE used by experienced surgeons $(p=0.000)$, as shown in Table 5 .

There was a statistically significant increase in CCT and PCT postoperatively in both Groups 1 and $2(p=0.000)$, as shown in Table 6.

Correlation studies revealed that grades of nuclear sclerosis were correlated with age $(r=0.56)$, and had positive correlation with difference in CCT and a weaker one with differences in PCT, but higher correlation with CDE, meaning that a higher grade of nuclear cataract was correlated with more increase in CCT, PCT and CDE levels. CDE had high positive correlation with difference in CCT $(r=0.72)$, moderate positive correlation with age $(r=0.51)$, nuclear sclerosis $(r=0.54)$ and differences in PCT $(r=0.52)$, meaning that higher levels of CDE was correlated with higher age, more increase in CCT or PCT, and higher grades of nuclear sclerosis, as shown in Table 7.

Partial correlation study after controlling for age, sex, endothelial standard deviation of cell size $\left(\mu \mathrm{m}^{2}\right)$, coefficient of variation of cell size (\%) and density $\left(\mu \mathrm{m}^{2}\right)$ revealed that eyes operated in Group 2 were correlated with higher differences in CCT, PCT and CDE, $r=0.50,0.60$ and 0.63 , respectively, and that $\mathrm{CDE}$ was correlated with higher CCT $(r=0.63)$ and PCT $(r=0.46)$, as shown in Table 8 .

Detailed comparisons using univariate ANOVA and post hoc tests showed that CDE used was significantly higher in

TABLE 1: Basic characteristics of study population.

\begin{tabular}{lcccc}
\hline Variable & Mean & Number & SD & $\%$ \\
\hline Age & 57.21 & - & 9.74 & - \\
Male & - & 49 & - & 49.0 \\
Female & - & 51 & - & 51.0 \\
Right eyes & - & 48 & - & 48.0 \\
Left eyes & - & 52 & - & 52.0 \\
\hline Total & - & $\mathbf{1 0 0}$ & - & 100.0 \\
\hline
\end{tabular}

SD, standard deviation. 
TABLE 2: Comparison between experienced and trainee surgeons according to age, preoperative central and peripheral corneal thickness.

\begin{tabular}{|c|c|c|c|c|c|c|c|}
\hline \multirow[t]{2}{*}{ Variable } & \multicolumn{2}{|c|}{ Group 1} & \multicolumn{2}{|c|}{ Group 2} & \multirow{2}{*}{$\begin{array}{l}\text { Difference } \\
\text { (Mean) }\end{array}$} & \multirow[t]{2}{*}{$T$} & \multirow[t]{2}{*}{$p$} \\
\hline & Mean & SD & Mean & SD & & & \\
\hline Age & 56.02 & 8.45 & 58.4 & 10.83 & 2.38 & 1.224 & 0.224 \\
\hline Pre-op CCT & 556.7 & 38.14 & 551.88 & 42.23 & 4.82 & 0.599 & 0.551 \\
\hline Pre-op PCT & 670.4 & 49.24 & 689.02 & 55.92 & 18.62 & 1.767 & 0.080 \\
\hline
\end{tabular}

Independent sample $T$-test, degree of freedom $=98$.

SD, standard deviation; CCT, central corneal thickness; PCT, peripheral corneal thickness.

TABLE 3: Comparison between experienced and trainee surgeons according to preoperative endothelium specular characteristics.

\begin{tabular}{|c|c|c|c|c|c|c|c|}
\hline \multirow[t]{2}{*}{ Variable } & \multicolumn{2}{|c|}{ Group 1} & \multicolumn{2}{|c|}{ Group 2} & \multirow{2}{*}{$\begin{array}{l}\text { Difference } \\
\text { (Mean) }\end{array}$} & \multirow[t]{2}{*}{$T$} & \multirow[t]{2}{*}{$p$} \\
\hline & Mean & SD & Mean & SD & & & \\
\hline Density/ $\mu \mathrm{m}^{2}$ & 2475.29 & 335.28 & 2509.82 & 319.92 & 34.53 & 0.527 & 0.599 \\
\hline Standard deviation of cell size $\mu \mathrm{m}^{2}$ (SD) & 139.31 & 16.68 & 141.14 & 21.82 & 1.82 & 0.471 & 0.639 \\
\hline Coefficient of variation $\%$ (CV) & 33.62 & 5.26 & 35.32 & 5.10 & 1.70 & 1.641 & 0.104 \\
\hline
\end{tabular}

Independent sample $T$-test, degree of freedom $=98$.

TABLE 4: The association between study groups and nuclear cataract grading.

\begin{tabular}{|c|c|c|c|c|c|c|c|}
\hline \multirow[t]{2}{*}{ Nuclear grading } & \multicolumn{2}{|c|}{ Group 1} & \multicolumn{2}{|c|}{ Group 2} & \multirow[t]{2}{*}{ Total } & \multirow[t]{2}{*}{$x^{2}$} & \multirow[t]{2}{*}{$p$} \\
\hline & Number & $\%$ & Number & $\%$ & & & \\
\hline 1 & 5 & 45.5 & 6 & 54.5 & 11 & \multirow{4}{*}{1.946} & \multirow{4}{*}{0.584} \\
\hline 2 & 9 & 60.0 & 6 & 40.0 & 15 & & \\
\hline 3 & 25 & 46.3 & 29 & 53.7 & 54 & & \\
\hline 4 & 10 & 62.5 & 6 & 37.5 & 16 & & \\
\hline Total & 49 & 51.0 & 47 & 49.0 & 96 & & \\
\hline
\end{tabular}

$\mathrm{X}^{2}$ (chi square test), degree of freedom $=3$.

TABLE 5: Comparison between Group 1 and Group 2 surgeons according to post-operative central corneal thickness, and post-operative peripheral corneal thickness and cumulative dissipated energy.

\begin{tabular}{|c|c|c|c|c|c|c|c|}
\hline \multirow[t]{2}{*}{ Variable } & \multicolumn{2}{|c|}{ Group 1} & \multicolumn{2}{|c|}{ Group 2} & \multirow{2}{*}{$\begin{array}{l}\text { Difference } \\
\text { (Mean) }\end{array}$} & \multirow[t]{2}{*}{$T$} & \multirow[t]{2}{*}{$p$} \\
\hline & Mean & SD & Mean & SD & & & \\
\hline Post-op CCT & 596.72 & 50.69 & 631.54 & 67.84 & 34.82 & 2.907 & 0.005 \\
\hline Post-op PCT & 734.8 & 88.55 & 883.18 & 128.43 & 148.38 & 6.725 & 0.000 \\
\hline $\mathrm{CDE} \dagger$ & 15.52 & 10.72 & 32.09 & 19.13 & 16.56 & $\dagger$ & 0.000 \\
\hline
\end{tabular}

Independent sample $T$-test, degree of freedom $=98$.

CCT, central corneal thickness; PCT, peripheral corneal thickness; SD, standard deviation; CDE, cumulative dissipated energy.

$\dagger$, Mann-Whitney U test.

TABLE 6: Comparison of preoperative with post-operative central and peripheral corneal thickness between Group 1 (number $=50$ ) and Group 2 (number $=50$ ).

\begin{tabular}{|c|c|c|c|c|c|c|c|}
\hline \multirow[t]{2}{*}{ Variable } & \multicolumn{2}{|c|}{ Pre-operative } & \multicolumn{2}{|c|}{ Post-operative } & \multirow{2}{*}{$\begin{array}{l}\text { Difference } \\
\text { (Mean) }\end{array}$} & \multirow[t]{2}{*}{$T$} & \multirow[t]{2}{*}{$p$} \\
\hline & Mean & SD & Mean & SD & & & \\
\hline \multicolumn{8}{|l|}{ Group 1} \\
\hline CCT & 556.7 & 38.14 & 596.72 & 50.69 & 40.02 & 9.883 & 0.000 \\
\hline РCT & 670.4 & 49.24 & 734.8 & 88.55 & 64.4 & 6.823 & 0.000 \\
\hline \multicolumn{8}{|l|}{ Group 2} \\
\hline CCT & 551.88 & 42.23 & 631.54 & 67.84 & 79.66 & 10.364 & 0.000 \\
\hline PCT & 689.02 & 55.92 & 883.18 & 128.43 & 194.16 & 10.941 & 0.000 \\
\hline
\end{tabular}

Paired sample $T$-test, Degree of freedom $=49$ (for each group).

$\mathrm{CCT}$, central corneal thickness; PCT, peripheral corneal thickness; SD, standard deviation; CDE, cumulative dissipated energy.

nuclear cataract graded as N4 compared to all lower grades $(p=0.000)$. Differences in CCT was significantly higher in N4 compared to $\mathrm{N} 1$ and N2 $(p=0.001)$, whilst no differences were statistically significant in PCT according to nuclear sclerosis grades $(p=0.092)$ mentioned, and further details were shown in Table 9.

Linear regression module in Table 9 showed that CCT changes were significantly linearly related to CDE in cases done by Group 1 surgeons, and that each increase in CDE by 5 units was associated with approximately $20.21 \mu \mathrm{m}$ increase in CCT, with a 95\% confidence interval of $12.00-28.42$, and that the increase in CDE by 5 units in Group 2 was associated with approximately $34.7 \mu \mathrm{m}$ increase in CCT, with a 95\% confidence interval of 13.0-56.3 as shown in Table 10 and illustrated in Figure 1.

Peripheral corneal thickness changes were significantly linearly related to $\mathrm{CDE}$ in both groups, and that in cases operated in Group 1, each increase in CDE by 5 units was associated with approximately $40.4 \mu \mathrm{m}$ increase in PCT, with a 95\% confidence interval of 10.9-69.9, whilst in cases operated in Group 2, each increase of CDE by 5 units was associated with approximately $132 \mu \mathrm{m}$ increase in PCT with a 95\% confidence interval of $90.0-174.9$, as shown in Table 11 and illustrated in Figure 2. 
TABLE 7: Correlations between age, sex, type of cataract, pre- and post-operative differences in central and peripheral corneal thickness and cumulative dissipated energy in both study groups.

\begin{tabular}{lccccc}
\hline Variables & Age & Sexף & $\begin{array}{c}\text { Nuclear } \\
\text { sclerosis }\end{array}$ & $\begin{array}{c}\text { Difference } \\
\text { in CCT }\end{array}$ & $\begin{array}{c}\text { Difference } \\
\text { in PCT }\end{array}$ \\
\hline Age & - & - & - & - & - \\
Sex & 0.002 & - & - & - & - \\
Nuclear sclerosis & $0.560^{* *}$ & -0.12 & - & - & - \\
Difference in CCT & $0.432 * *$ & -0.084 & $0.393^{* *}$ & - & - \\
Difference in PCT & $0.228^{*}$ & -0.123 & $0.223^{*}$ & $0.527 * *$ & - \\
CDE & $0.510^{* *}$ & -0.119 & $0.539 * *$ & $0.716^{* *}$ & $0.518^{* *}$ \\
\hline
\end{tabular}

$\mathrm{CCT}$, central corneal thickness; $\mathrm{PCT}$, peripheral corneal thickness; CDE, cumulative dissipated energy.

$*, p<0.05$.

$* *, p<0.001$.

q, Pearson correlation: Spearman correlation was used for sex only.

TABLE 8: Partial correlation model between surgeon type with pre- and postoperative differences in central and peripheral corneal thickness and cumulative dissipated energy, controlling for age, sex, nuclear sclerosis density and endothelium specular findings.

\begin{tabular}{lccc}
\hline Variables & Surgeon (Trainee) & Difference in CCT & Difference in PCT \\
\hline Difference in CCT & $0.500^{* *}$ & - & - \\
Difference in PCT & $0.601^{* *}$ & $0.458^{* *}$ & - \\
CDE & $0.627^{* *}$ & $0.632^{* *}$ & $0.464 * *$ \\
\hline
\end{tabular}

CCT, central corneal thickness; PCT, peripheral corneal thickness; $C D E$, cumulative dissipated energy.

**, Pearson correlation: $p<0.001$

TABLE 9: Comparison between cumulative dissipated energy, pre- and postoperative differences in central and peripheral corneal thickness amongst grades of nuclear cataract.

\begin{tabular}{lcccc}
\hline Variables & Mean & SD & $\boldsymbol{F}$ & $\boldsymbol{p}$ \\
\hline CDE & & & & \\
N1 & $5.39^{\mathrm{n} 2, \mathrm{n} 3 \mathrm{n} \text { 4 }}$ & 5.783 & & \\
N2 & $16.98^{\mathrm{n} 1, \mathrm{n} 4}$ & 13.85 & 12.619 & 0.000 \\
N3 & $26.78^{\mathrm{n} 1, \mathrm{n} 3 \mathrm{n} 4}$ & 15.69 & & \\
N4 & $38.45^{\mathrm{n} 1, \mathrm{n} 2 \mathrm{n} \text { n }}$ & 16.30 & & \\
Difference in CCT & & & & \\
N1 & $21.36^{\mathrm{n} 3, \mathrm{n} 4}$ & 23.09 & & \\
N2 & $50.2^{\mathrm{n} 4}$ & 61.59 & & \\
N3 & $64.05^{\mathrm{n} 1}$ & 41.11 & & \\
N4 & $91.5^{\mathrm{n} 1, \mathrm{n} 2}$ & 47.94 & & \\
Difference in PCT & & & & \\
N1 & 84.54 & 101.47 & & \\
N2 & 124.0 & 147.45 & \multirow{2}{*}{2.213} & 0.092 \\
N3 & 125.98 & 108.08 & & \\
N4 & 195.93 & 132.47 & & \\
\hline
\end{tabular}

$\mathrm{N} 1=11, \mathrm{~N} 2=15, \mathrm{~N} 3=54, \mathrm{~N} 4=16$ and Total $=96$

$\mathrm{n} 1, \mathrm{n} 2, \mathrm{n} 3$ and $\mathrm{n} 4$ : significant Tukey's post hoc test with N1, N2, N3 and N4, respectively. ANOVA, analysis of variances; $\mathrm{N}$, nuclear cataract; $\mathrm{CCT}$, central corneal thickness; PCT, peripheral corneal thickness; SD, standard deviation; CDE, cumulative dissipated energy.

\section{Discussion}

In the current study, the mean age of patients was $57.21 \pm$ 9.74 years, with very close male to female, and right to left eyes ratios, which decrease bias in this study. Other related studies showed a higher mean age - as Briszi et al. ${ }^{23}$ study, which was done in a tertiary centre in Germany in order to review the risk factors and complications of the first 100 operations done by resident doctors with a mean age of $71.4 \pm 10.9$, and also Lhuillier et al. ${ }^{9}$ study, done in France, which included 110 patients operated by seniors, and 50 cases operated by junior doctors, and their mean age was $71.5 \pm 9.1$ years. In Iraq, a study done in Mosul city by Rajab et al. ${ }^{24}$ included 2440 patients who underwent cataract
TABLE 10: Linear regression prediction of central corneal thickness increase according to cumulative dissipated energy used during phaco.

\begin{tabular}{lcc}
\hline Variables & Group 1 & Group 2 \\
\hline CCT increase for 5 units increase & $20.21(12.00-28.42)$ & $34.7(13.0-56.3)$ \\
in CDE (Value, 95\% Cl) & 0.000 & 0.000 \\
$p$ & $10.80+1.882 \mathrm{CDE}$ & $26.1+1.704 \mathrm{CDE}$ \\
\hline
\end{tabular}

Group 1, $R^{2}=49.73 \%$; Group 2, $R^{2}=37.36 \%$.

$\mathrm{CCT}$, central corneal thickness; $\mathrm{CDE}$, cumulative dissipated energy; $\mathrm{Cl}$, confidence interval.

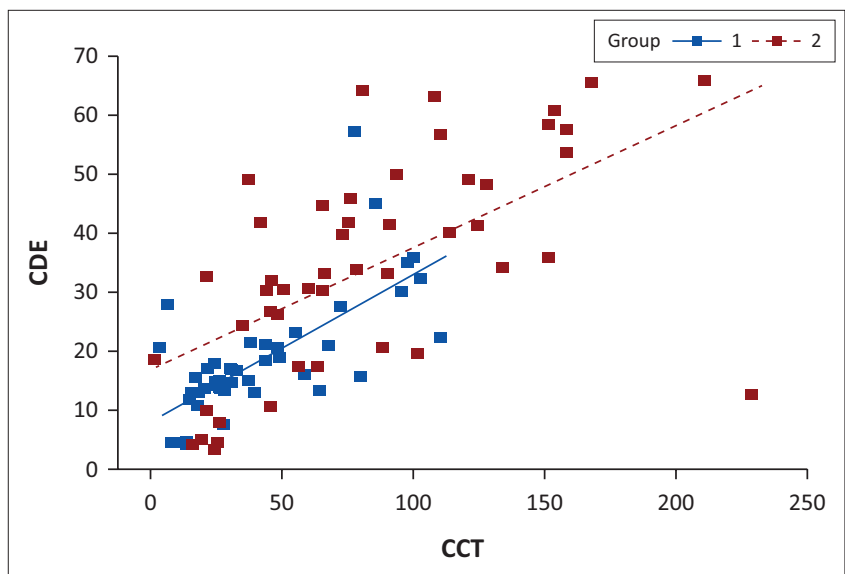

$\mathrm{CDE}$, cumulative dissipated energy; $\mathrm{CCT}$, central corneal thickness.

FIGURE 1: Fitted line plot between cumulative dissipated energy and difference in central corneal thickness post-operatively.

TABLE 11: Linear regression prediction of peripheral corneal thickness increase according to cumulative dissipated energy used during phaco.

\begin{tabular}{lcc}
\hline Variables & Group 1 & Group 2 \\
\hline PCT increase for 5 units increase & $40.4(10.9-69.9)$ & $132.0(90.0-174.9)$ \\
in CDE (Value, 95\% Cl) & 0.000 & 0.000 \\
$p$ & $29.0+2.279 \mathrm{CDE}$ & $121.0+2.279 \mathrm{CDE}$ \\
\hline
\end{tabular}

Group 1, $R^{2}=49.98 \%$; Group 2, $R^{2}=38.50 \%$.

$\mathrm{CCT}$, central corneal thickness; PCT, peripheral corneal thickness; CDE, cumulative dissipated energy; $\mathrm{Cl}$, confidence interval.

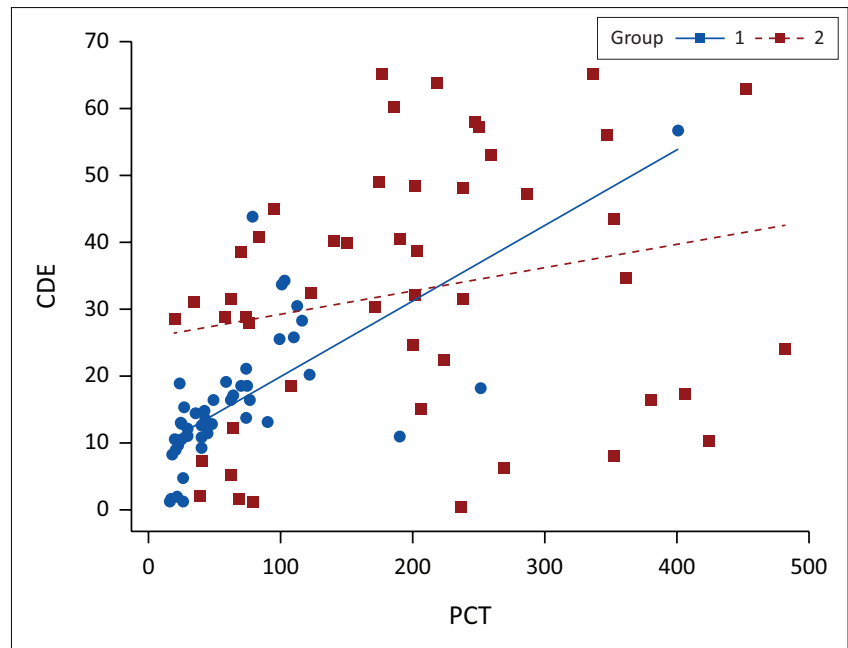

$\mathrm{CDE}$, cumulative dissipated energy; PCT, peripheral corneal thickness.

FIGURE 2: Fitted line plot between cumulative dissipated energy and difference in peripheral corneal thickness post-operatively.

surgery, and it was similar to the current study; they reported lower age than the previously mentioned studies, which could be attributed to the higher UVA light levels in Iraq compared to global values, ${ }^{25}$ which accelerate ageing of 
crystalline lens. ${ }^{26}$ Pre-operatively, there were no significant differences in demographics, CCT, PCT and endothelial specular microscopy findings between the two groups.

In the current study, there was a significantly higher postoperative CCT in Group 2 compared to Group 1 with a difference of $34.82 \mu \mathrm{m} \pm 2.907 \mu \mathrm{m}$. These results were similar to the results of Lhuillier et al., ${ }^{9}$ as they reported an increase in CCT in junior group by $35.9 \mu \mathrm{m}$ more than senior group. Also in the current study, there was a significant increment in CCT post-operatively in both Group 1 and Group 2, by $40.02 \mu \mathrm{m}$ and $79.66 \mu \mathrm{m}$, respectively. These results were slightly lower than the results reported by Lhuillier et al., ${ }^{9}$ as they reported $105.8 \mu \mathrm{m}$ increase in CCT in junior surgeons group compared to $66.4 \mu \mathrm{m}$ increase in CCT in senior group. Aribada et al. ${ }^{27}$ had reported that corneal thickness increases acutely at the first post-operative day, then decline progressively reaching close to the preoperative reading at the eighth week post-operatively, and even the contralateral eye have a mild increase in thickness, which indicated that there are more factors, rather than just endothelial cell loss, that were responsible for thickness increment, although endothelial cell loss is a recognised sequelae of phacoemulsification. ${ }^{12,13,28,29}$

In the current study, measurement of PCT was done at the site of main incision, and surgeon experience had highest correlation with difference in PCT than with difference in CCT; to the best of our knowledge, there was no previous published literature about the difference of PCT between experienced and trainee surgeons, and paucity of studies regarding effect of cataract surgeries on PCT. Lundberg et $\mathrm{al}^{30}$ in Sweden had reported that PCT increase after phacoemulsification was related to peripheral corneal oedema, and also they reported a moderate correlation between peripheral and central corneal cell losses. Excessive manipulations and movements of phaco tip might increase the thickness and cell loss of the periincisional corneal area. Other factors may include turbulent currents of the irrigation fluid, local wound burn, Descemet's membrane detachment, excessive wound stromal hydration and cavitation bubbles that are not related to the incision site only. ${ }^{31}$

In the current study, increasing nuclear sclerosis grade was correlated with higher CDE, older age, higher CCT and PCT changes, and this was in agreement with Ojha ${ }^{32}$ in India, who enrolled 50 eyes, and studied the effect of nuclear density according to Lens Opacities Classification System III (LOCS III) grading system, ${ }^{33}$ and found that effective phaco time increases with increasing nuclear density, and higher grades were associated with older age. LaudańskaOlszewska et al. ${ }^{34}$ in Poland reported that nuclear density was associated with higher energy and phaco time, but was not significantly associated with CCT increment or endothelial cell loss.
In the current study, CDE was strongly correlated with differences in CCT and moderately correlated with differences in PCT, and this was in agreement with the results of Belyea et al. ${ }^{35}$ and Taravella et al., ${ }^{36}$ who showed that ultrasound power and phaco time decrease with improving surgeon's experience, also Lhuillier et al., ${ }^{9}$ who showed that surgery time decreased with better surgeon experience, resulting in a lower ultrasound time, and so lower post-operative corneal oedema.

The corneal endothelium dysfunction, stress and cell death impairing its pumping action following phacoemulsification could be attributed to the release of free radicals in anterior chamber generated by ultrasound power, ${ }^{37}$ and to other factors related to the procedure itself rather than ultrasound, which might include local anterior chamber inflammation that occurs to a degree after uncomplicated cataract surgery, whilst mechanical trauma and heat are mainly responsible for decreased endothelial density, ${ }^{38}$ and endothelial cells respond by cellular enlargement and to a lower extent by migration in the early period of recovery from cataract surgery, ${ }^{39}$ and normally without replication. ${ }^{40}$

Phacoemulsification is a surgical procedure that requires a high degree of precision and skill with a learning curve that is crafted by repetition. Vedana et $a .^{41}$ had reported that a minimum of 30 extracapsular cataract extraction operations should be done by a resident ophthalmologist prior to start phacoemulsification, and that a minimum of 38 phacoemulsification were needed by residents to reach competency.

Limitations and drawbacks of the study were related to the fact that these surgeries were operated by more than one experienced surgeon, using more than one technique of phacoemulsification and by more than one trainee surgeon in two levels of training. Also cataract grading system used in this study was subjective one, with the possibility of being non-reproducible.

\section{Conclusion}

- Phacoemulsification operations done by trainee surgeons were associated with higher CCT, PCT and more CDE was used.

- Regardless of surgeons' experience, a higher grade of nuclear cataract was correlated with higher age, more increase in CCT, PCT and CDE levels, and the latter was also correlated with higher age, more increase in CCT or PCT.

\section{Recommendation}

Following a predefined curriculum regarding surgical training of residents, including the sooner introduction of cataract surgery to their training programme in conjunction with attending lectures and wet labs is expected to fasten their acquisition of skills and reducing complication rates. 


\section{Acknowledgements}

\section{Competing interests}

The authors have declared that no competing interests exist.

\section{Authors' contributions}

All authors contributed equally to this work.

\section{Funding information}

This research received no specific grant from any funding agency in the public, commercial or not-for -profit sectors.

\section{Data availability statement}

Data sharing is not applicable to this article.

\section{Disclaimer}

This views and opinions expressed in this article are those of the authors and do not necessarily reflected the official policy or position of any affiliated agency of the authors.

\section{References}

1. Lundstrom M, Stenevi U, Thorburn W. The Swedish National Cataract Register A 9-year review. Acta Ophthalmol Scand. 2002;80(3):248-257. https://doi org/10.1034/j.1600-0420.2002.800304.x

2. Tao A, Chen Z, Shao $Y$, et al. Phacoemulsification induced transient swelling of corneal Descemet's endothelium complex imaged with ultra-high resolution optical coherence tomography. PLoS One. 2013;8(11):e80986. https://doi. org/10.1371/journal.pone.0080986

3. Jeon HS, Hyon JY. Effects of central corneal thickness on early postoperative corneal edema after phacoemulsification. JSM Ophthalmol. 2016;4(2):1044.

4. Porela-Tiihonen S, Kokki H, Kaarniranta K, Kokki M. Recovery after cataract surgery. Acta Ophthalmol. 2016;94(A2):1-34. https://doi.org/10.1111/aos. 13055

5. Miyata K, Nagamoto T, Maruoka S, Tanabe T, Nakahara M, Amano S. Efficacy and safety of the soft-shell technique in cases with a hard lens nucleus. J Cataract Refract Surg. 2002;28(9):1546-1550. https://doi.org/10.1016/S0886-3350(02) 01323-8

6. Kim EK, Cristol SM, Kang SJ, Edelhauser HF, Yeon DS, Lee JB. Endothelial protection Avoiding air bubble formation at the phacoemulsification tip. J Cataract Refract Surg. 2002;28(3):531-537. https://doi.org/10.1016/\$0886-3350(01)01155-5

7. Suzuki $H$, Igarashi $T$, Shiwa $T$, Takahashi $H$. Efficacy of ophthalmic viscosurgical devices in preventing temperature rise at the corneal endothelium during phacoemulsification. Curr Eye Res. 2016;41(12):1548-1552. https://doi.org/10.3 109/02713683.2015.1136420

8. Behndig A, Lundberg B. Transient corneal edema after phacoemulsification: Comparison of 3 viscoelastic regimens. J Cataract Refract Surg. 2002;28(9): 1551-1556. https://doi.org/10.1016/S0886-3350(01)01219-6

9. Lhuillier L, Jeancolas AL, Renaudin L, et al. Impact of ophthalmic surgeon experience on early postoperative central corneal thickness after cataract surgery
Cornea. 2017;36(5):541-545. https://doi.org/10.1097/ICO.0000000000001175

10. Sharma N, Singhal D, Nair S, Sahay P, Sreeshankar S, Maharana P. Corneal edema after phacoemulsification. Indian J Ophthalmol. 2017;65(12):1381-1389. https:// doi.org/10.4103/ijo.IJO_871_17

11. Van den Bogerd B, Dhubhghaill SN, Koppen C, Tassignon M-J, Zakaria N. A review of the evidence for in vivo corneal endothelial regeneration. Surv Ophthalmol. 2018;63(2):149-165. https://doi.org/10.1016/j.survophthal.2017.07.004

12. Peyrot DA, Aptel F, Crotti $C$, et al. Effect of incident light wavelength and corneal edema on light scattering and penetration: Laboratory study of human corneas. J Refract Surg. 2010;26(10):786-795. https://doi.org/10.3928/108159 7X-20100921-04

13. Bourne RR, Minassian DC, Dart JK, Rosen P, Kaushal S, Wingate N. Effect of cataract surgery on the corneal endothelium: Modern phacoemulsification compared with extracapsular cataract surgery. Ophthalmology. 2004;111(4):679-685. https:// doi.org/10.1016/j.ophtha.2003.07.015

14. Walkow T, Anders N, Klebe S. Endothelial cell loss after phacoemulsification Relation to preoperative and intraoperative parameters. J Cataract Refract Surg. 2000;26(5):727-732. https://doi.org/10.1016/S0886-3350(99)00462-9

15. O'Brien PD, Fitzpatrick P, Kilmartin DJ, Beatty S. Risk factors for endothelial cell loss after phacoemulsification surgery by a junior resident. J Cataract Refract Surg. 2004;30(4):839-843. https://doi.org/10.1016/S0886-3350(03)00648-5
16. Ellis EM, Saunders L, Lee JE, Haw WW, Granet DB, Heichel CW. Complication rates of resident-performed cataract surgery: Impact of early introduction of cataract surgery training. J Cataract Refract Surg. 2018;44(9):1109-1115. https://doi. surgery training. J Cataract Refra
org/10.1016/j.jcrs.2018.06.022

17. Al-Ageel S, Al-Muammar AM. Comparison of central corneal thickness measurements by Pentacam, noncontact specular microscope, and ultrasound pachymetry in normal and post-LASIK eyes. Saudi J Ophthalmol. 2009;23(3-4): 181-187. https://doi.org/10.1016/j.sjopt.2009.10.002

18. De Sanctis U, Missolungi A, Mutani B, Richiardi L, Grignolo FM. Reproducibility and repeatability of central corneal thickness measurement in keratoconus using the rotating Scheimpflug camera and ultrasound pachymetry. Am J Ophthalmol. 2007;144(5):712-718. https://doi.org/10.1016/j.ajo.2007.07.021

19. Huang J, Ding X, Savini G, et al. A Comparison between Scheimpflug imaging and optical coherence tomography in measuring corneal thickness. Ophthalmology. 2013;120(10):1951-1958. https://doi.org/10.1016/j.ophtha.2013.02.022

20. Kuerten D, Plange N, Koch EC, Koutsonas A, Walter P, Fuest M. Central corneal thickness determination in corneal edema using ultrasound pachymetry, Scheimpflug camera, and anterior segment OCT. Graefes Arch Clin Exp Ophthalmol. 2015;253(7):1105-1109. https://doi.org/10.1007/s00417-015-2998-y

21. Thylefors B, Chylack Jr L, Konyama K, et al. A simplified cataract grading system The WHO Cataract Grading Group. Ophthalmic epidemiology. 2002;9(2):83-95. https://doi.org/10.1076/opep.9.2.83.1523

22. Chen M, Anderson E, Hill G, Chen JJ, Patrianakos T. Comparison of cumulative dissipated energy between the Infiniti and Centurion phacoemulsification systems. Clin Ophthalmol. 2015;9:1367-1372. https://doi.org/10.2147/OPTH.S88225

23. Briszi A, Prahs P, Hillenkamp J, Helbig H, Herrmann W. Complication rate and risk factors for intraoperative complications in resident-performed phacoemulsification surgery. Graefes Arch Clin Exp Ophthalmol. 2012;250(9):1315-1320. https://doi. surgery. Graefes Arch Clin Exp Opht
org/10.1007/s00417-012-2003-y

24. Amer YR. Cataract surgery rate in Mosul city. Ann Coll Med Mosul. 2008;34(1) 76-80. https://doi.org/10.33899/mmed.2008.8950

25. Alsalihi AM, Abdulatif SH. Analysis global and ultraviolet radiation in Baghdad City, Iraq. Analysis. 2016;6(22):117-124.

26. Linetsky M, Raghavan $\mathrm{CT}$, Johar $\mathrm{K}$, et al. UVA light-excited kynurenines oxidize ascorbate and modify lens proteins through the formation of advanced glycation end products: Implications for human lens aging and cataract formation. J Biol Chem. 2014;289(24):17111-17123. https://doi.org/10.1074/ jbc.M114.554410

27. Aribaba OT, Adenekan OA, Onakoya AO, et al. Central corneal thickness changes following manual small incision cataract surgery. Clin Ophthalmol. 2015;9: 151-155. https://doi.org/10.2147/OPTH.S75580

28. Bamdad S, Bolkheir A, Sedaghat MR, Motamed M. Changes in corneal thickness and corneal endothelial cell density after phacoemulsification cataract surgery: A double-blind randomized trial. Electron Phys. 2018;10(4):6616-6623. https:// doi.org/10.19082/6616

29. Thakur SK, Dan A, Singh M, Banerjee A, Ghosh A, Bhaduri G. Endothelial cell loss after small incision cataract surgery. Nepal J Ophthalmol. 2011;3(2):177-180. https://doi.org/10.3126/nepjoph.v3i2.5273

30. Lundberg B, Jonsson M, Behndig A. Postoperative corneal swelling correlates strongly to corneal endothelial cell loss after phacoemulsification cataract surgery. Am Ophthalmol. 2005;139(6):1035-1041. https://doi.org/10.1016/j.ajo.2004.12.080

31. Kaup S, Shivalli S, Divyalakshmi K, Arunachalam C, Varghese RC. Central corneal thickness changes in bevel-up versus bevel-down phacoemulsification cataract surgery: Study protocol for a randomised, triple-blind, parallel group trial. BMJ Open. 2016;6(9):e012024. https://doi.org/10.1136/bmjopen-2016-012024

32. Ojha T. Study of nuclear hardness and phaco time in phacoemulsification. Int J Sci Study. 2017;5(9):44-47.

33. Chylack LT, Wolfe JK, Singer DM, et al. The lens opacities classification system III. Arch Ophthalmol. 1993;111(6):831-836. https://doi.org/10.1001/archopht.1993. 01090060119035

34. Laudańska-Olszewska I, Synder A, Wesołek-Czernik A, Omulecki W. Comparison of efficacy and safety of cataract phacoemulsification in patients with different degree of nuclear sclerosis. Klinika Oczna. 2008;110(4-6):172-175.

35. Belyea DA, Brown SE, Rajjoub LZ. Influence of surgery simulator training on ophthalmology resident phacoemulsification performance. J Cataract Refract Surg. 2011;37(10):1756-1761. https://doi.org/10.1016/j.jcrs.2011. 04.032

36. Taravella MJ, Davidson R, Erlanger M, Guiton G, Gregory D. Time and cost of teaching cataract surgery. J Cataract Refract Surg. 2014;40(2):212-216. https:// doi.org/10.1016/j.jcrs.2013.07.045

37. Murano N, Ishizaki M, Sato S, Fukuda Y, Takahashi H. Corneal endothelial cell damage by free radicals associated with ultrasound oscillation. Arch Ophthalmol. 2008;126(6):816-821. https://doi.org/10.1001/archopht.126.6.816

38. Han SB, Kim M, Lee S-J, Yang HK. Pathophysiology of transient corneal edema and pseudophakic cystoid macular edema. Kor J Ophthalmol. 2015;29(3):203-204. https://doi.org/10.3341/kjo.2015.29.3.203

39. Kim DH, Wee WR, Hyon JY. The pattern of early corneal endothelial cell recovery following cataract surgery: Cellular migration or enlargement? Graefes Arch Clin Exp Ophthalmol. 2015;253(12):2211-2216. https://doi.org/10.1007/s00417-0153100-5

40. Joyce NC. Cell cycle status in human corneal endothelium. Exp Eye Res. 2005;81(6):629-638. https://doi.org/10.1016/j.exer.2005.06.012

41. Vedana G, Cardoso FG, Marcon AS, et al. Cumulative sum analysis score and phacoemulsification competency learning curve. Int J Ophthalmol. 2017;10(7): 1088-1093. 